\title{
The Effect of Work-Life Balance and Work Stress on Turnover Intention with Job Satisfaction as A Mediator at Anti-Corruption Institution in Indonesia
}

\author{
Febria Angelina Lebang ${ }^{1, *}$ Niken Ardiyanti ${ }^{2}$
}

\author{
${ }^{1}$ Universitas Indonesia \\ ${ }^{2}$ Universitas Indonesia \\ *Corresponding author.Email: angel.of.ina@gmail.com
}

\begin{abstract}
The number of corruption cases in Indonesia that have been revealed from every year has given to the workload of employees to take action on the cases to completion in restoring financial state losses that is caused from corruption. The job characteristic that requires employees to be available at all times has also affected the balancing of two domains: work and non-work, especially employees who work in the office of deputy for enforcement. This research aims to examine the relationship between work life balance and work stress on turnover intention and the effect of job satisfaction in mediating relationships between these variables among employees of Deputy for Enforcement of AntiCorruption Institution in Indonesia. This research was conducted by using quantitative method through the distribution of questionnaires. An amount of 218 respondents were obtained as a sample of a population of 427 specialist and administrative employees. Hypotheses were tested with structural equation modeling (SEM) using Amos 23. The results found that there were positive influences on the relationships between work stress and turnover intention, both directly and indirectly through the mediation of job satisfaction. The results also revealed that there was no direct effect on work-life balance and turnover intention relationship, but indirect effect was found through the mediation of job satisfaction.
\end{abstract}

Keywords: Work-Life Balance, Work Stress, Job Satisfaction, Turnover Intention.

\section{INTRODUCTION}

The number of corruption cases in Indonesia in the past few years has prompted the Anti-Corruption Institution in Indonesia to crack down the cases to completion. Enforcement of corruption cases is important to restore state financial losses resulting from these acts of corruption. The institution formed in 2002 is one of ninety-seven non-structural institutions in Indonesia, and is independent. Its distinctive character and added duties and responsibilities to eradicate corruption make this institution have job characteristics that require employees to be available at all times, especially in carrying out the task of prosecuting corruption. Workload, which is one of the triggers for work stress, and time, which is an important part in forming work-life balance, is seen as two things that can affect employee turnover intention. Work-life balance talks about the ideal balance between an individual's personal and professional life [1]. Managing conflicts between work and life is a big challenge for organizations and individuals [2]. Research conducted by [3]

Found that every disruption between work and family creates dissatisfaction among workers. This dissatisfaction can ultimately have an impact on the desire to leave his current job (turnover intention). In addition to work-life balance, another thing that can also affect the job satisfaction of a worker is work stress. Work stress is a feeling of distress felt by workers in the face of their work, which can be triggered by working conditions, excessive burdens, and interpersonal relationships with colleagues by Anwar, 1993 and Robbins, 2008. The high work stress causes a high level of desire to get out of work [4]. Just like work stress, job satisfaction is also considered an important predictor and shows a significant inverse relationship with turnover intention [4]. 
Many studies have been conducted to prove the effect of work-life balance, work stress, and job satisfaction on turnover intention. Most of the research was carried out in the private sector. Because of the special characteristics of Indonesia's anti-corruption institutions, this research was conducted to see whether there were similarities in results with previous research or there were differences due to the uniqueness of the characteristics of the research object.

This research was focused on administrative and specialist employees who worked in the Deputy for Enforcement of Anti-Corruption Institution in Indonesia. The purpose of this research was to examine the relationship between work life balance and work stress on turnover intention and the effect of job satisfaction in mediating relationships between these variables among employees of Deputy for Enforcement of AntiCorruption Institution in Indonesia.

\section{METHODS}

\subsection{Participants and sampling}

The population in this research was employees of the Deputy for Enforcement of Anti-Corruption Institution in Indonesia. Based on data received from the Secretariat of the Deputy for Enforcement on April 2, 2019, the number of employees in the Deputy for Enforcement of AntiCorruption Institution in Indonesia was 434 employees, consisting of 7 structural-level employees, 346 specialistlevel employees, and 81 administrative-level employees. The focus of the research

Was employees at specialist and administrative level. Then, the total population becomes 427 employees. The research sample was taken using the Slovin's formula. Because the population was not too large which was between 100-500, it can use a 5\% margin error [5]. Thus the number of samples in this study based on (1).

$$
\begin{aligned}
n=\frac{N}{1+N(e)^{2}} n=\frac{N}{1+N(e)^{2}} & \\
n=\frac{N}{1+N(e)^{2}} & =\frac{427}{1+427(0,05)^{2}}=206,53 \\
& \approx 207
\end{aligned}
$$

Where $n$ =sample size, $N=$ population, $e=$ eror margin

\subsection{Measuring instruments}

The questionnaire was divided into five main parts. The first part contains questions related to the identity of the respondent including gender, age range, marital status, education background, and years of service, occupation, roles, work units, and types of work time. The other four sections contain statements from each research variable.
To obtain work-life balance related data, the research used six items of questionnaires used by referenece [6] in their study, where two items were adapted from a questionnaire developed by reference [7] about supervisor work-life balance support and four items were adapted from reference [8] about employees' perception about work-life balance. There were eight work stress questionnaire items adapted from [4], consist of four items about workload and four items about negative emotions. There are twenty-three job satisfaction questionnaire items adapted from the questionnaire used by [4] in their study, which came from a questionnaire built by research team of Xi'an Jiaotong University, consist of seven items about reward satisfaction, four items about social recognition satisfaction, four items about organizational management satisfaction, and eight items about occupation satisfaction. To measure turnover intention, items to be used are selected from a questionnaire developed by Camman et al (1979) and Mobley (1977), as used by reference [9]. All variables were assessed on six-point Likert scale ranging from 1 (highly disagree/highly dissatisfied) to 6 (highly agree/highly satisfied). The questionnaire was compiled, and then proof reading was carried out on the questionnaire. Proof reading aimed to determine the understanding of each item in the questionnaire. Then a pretest was conducted to measure the validity and reliability of the research instrument. The pretest was conducted for eight days, starting on February 15, 2019 until February 22, 2019 with a total of 33 valid respondents.

\subsection{Hypotheses}

The previous studies found that work family conflict had a direct effect on turnover intention $[9,10]$. Work interfere with family was believed to positively influence turnover intention [3, 11]. Reference [12] in their study also stated that work life balance was the most significant cant predictor (compared to supervisory behavior and job characteristics) in influencing employee turnover intention. Based on the results of previous studies, the following hypotheses are made:

H1: Work-life balance will influence turnover intention negatively.

Klassen said in reference [13] found that high work stress felt by employees had turnover intention implications. In addition, Reference $[9,14]$ study found that there was an association between work stress and turnover intention. The same finding was also shown by reference [13], who revealed that work stress affects the intention to leave. Based on the results of previous studies, the following hypotheses are made:

$\mathrm{H} 2$ : Work stress influenced turnover intention positively.

Previous research found that work to family conflict and family to work conflict were negatively correlated 
with job satisfaction $[3,15]$. It is in line with the opinions of reference [6] who emphasized the importance of organizations paying attention to the work-life balance of their employees. By doing so, job satisfaction can also increase. Reference [9] also found that work family conflict had a direct effect on job satisfaction. Based on the results of previous studies, the following hypotheses were made:

H3: Work-life balance influenced job satisfaction positively.

Reference [16] conducted a study to know the influence of work stress and work motivation in job satisfaction. They found that work stress negatively affected job satisfaction. Besides, a study conducted by [17] to doctors who worked in hospitals also found that there was a direct negative relationship between work stress and job satisfaction. In addition, the same results were shown through the study conducted by [4,9] Based on the results of previous studies, the following hypotheses were made:

H4: Work stress influenced job satisfaction negatively.

$[10,18]$ found that there was an association between job satisfaction and turnover intention which made employees feel dissatisfied with their work and distrusted by their organizations, so that they desired to leave becomes even greater. Several studies also proved that job satisfaction negatively influenced turnover intention $[4,9,13,17]$. Based on the results of previous studies, the following hypotheses were made:

H5: Job satisfaction influenced turnover intention negatively.

Reference [9] found that job satisfaction succeeded in mediating the relationship between work family conflict and turnover intention, where the significance value of mediation relationship was greater than the significance value of the direct relationship between work family conflict and turnover intention. Likewise reference [10], who found that job satisfaction significantly, mediated the relationship between work-life conflict and turnover intention. Based on the results of previous studies, the following hypotheses were made:

H6: Job satisfaction mediated the relationship between work-life balance and turnover intention.

Previous studies found that job satisfaction mediates the relationship between work stress and turnover intention [9], [17]. In a study conducted on health workers in eleven provinces in China, reference [4] found that employees who had turnover intention showed lower job satisfaction and higher work stress than those who did not have turnover intention. Furthermore, reference [4] concluded that job satisfaction plays a mediating role in the relation of work stress to turnover intention. Based on the results of previous studies, the following hypotheses are made:

H7: Job satisfaction will mediate the relationship between work stress and turnover intention.

From the above hypotheses, the research model can be described as follows fig. 1 .

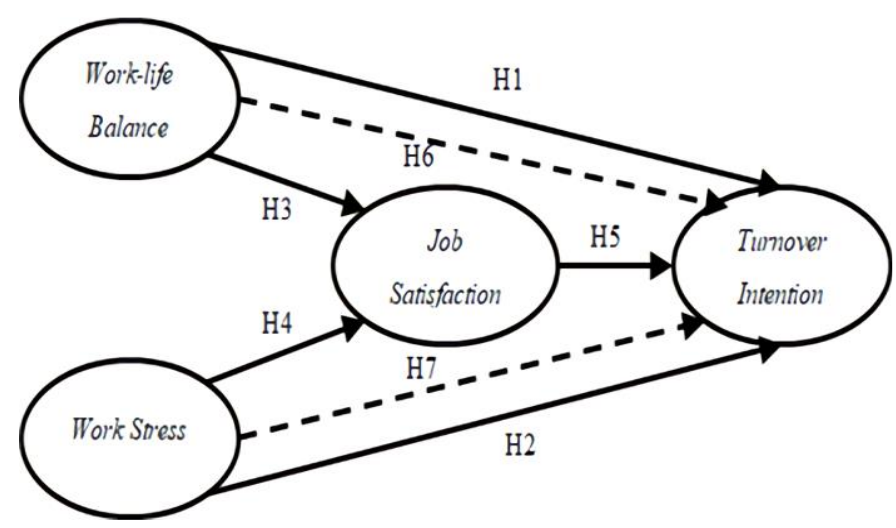

Figure 1 Hypotheses model

\section{RESULTS AND DISCUSSION}

\subsection{Socio-demographic information of participants}

Based on the The main test was carried out from 1 April 2019 until 3 May 2019. The questionnaire was distributed in hard copies of 250 copies and in digital form through Google Form to 433 employees of Deputy for Enforcement. There was 250 print questionnaires, and there were returned 92 or had a response rate of $36.8 \%$ and only 91 copies could be further processed. While of the 433 employees who were given a digital questionnaire, 127 employees gave a response back or had a response rate of $29.3 \%$ and all of them could be further processed. Thus, there are 218 questionnaires that can be continued to the next process. This number has fulfilled the needs of 207 samples.

The main test was carried out from 1 April 2019 until 3 May 2019. The questionnaire was distributed in hard copies of 250 copies and in digital form through Google Form to 433 employees of Deputy for Enforcement. There were 250 print questionnaires, and there were returned 92 or had a response rate of $36.8 \%$ and only 91 copies could be further processed. While of the 433 employees who were given a digital

Table_questionnaire, 127 employees gave a response back or had a response rate of $29.3 \%$ and all of them could be further processed. Thus, there are 218 questionnaires that can be continued to the next process. This number has fulfilled the needs of 207 samples based on table 1 . 
Table 1. Socio-Demographic Information of Participants

\begin{tabular}{|c|c|c|c|}
\hline Information & $\mathbf{N}(\%)$ & Information & $\mathbf{N}(\%)$ \\
\hline Gender & & Years of service & \\
\hline Male & $138(63.3)$ & $\leq 5$ & $98(45.0)$ \\
\hline Female & $80(36.7)$ & $6-10$ & $70(32.1)$ \\
\hline Age range & & $>10$ & $50(22.9)$ \\
\hline$<25$ & $7(3.2)$ & Occupation & \\
\hline $25-35$ & $119(54.6)$ & Administrative & $53(24.3)$ \\
\hline $36-40$ & $55(25.2)$ & Specialist & $165(75.7)$ \\
\hline $41-45$ & $20(9.2)$ & Role & \\
\hline $46-50$ & $11(5.0)$ & Team member & $182(83.5)$ \\
\hline $51-55$ & $5(2.3)$ & Team leader & $36(16.5)$ \\
\hline$>55$ & $1(0.5)$ & & \\
\hline Marital status & & Work unit & \\
\hline Unmarried & $58(26.6)$ & LID & $61(28.0)$ \\
\hline Married & $160(73.4)$ & DIK & $58(26.6)$ \\
\hline Education & & TUT & $34(15.6)$ \\
\hline High School & $0(0)$ & LABUKSI & $29(13.3)$ \\
\hline Diploma & $14(6.4)$ & KORWIL & $32(14.7)$ \\
\hline Bachelor & $150(68.8)$ & SET & $4(1.8)$ \\
\hline Master & $52(23.9)$ & Work time & \\
\hline Doctor & $2(0.9)$ & Flexi & $216(99.1)$ \\
\hline & & Regular & $2(0.9)$ \\
\hline
\end{tabular}

Overall, the level of work life balance, work stress, and job satisfaction were rather high, while the level of turnover intention was rather low based on table 2 .

Table 2. Item Scores In Work-Life Balance, Work Stress, Job Satisfaction, and Turnover Intention

\begin{tabular}{|c|c|}
\hline Item & Mean \\
\hline Work-life balance & 4,13 \\
\hline The company facilitates work-life balance. & 4,81 \\
\hline My supervisor emphasize work-life balance. & 4,48 \\
\hline There is enough time for recreation activities. & 4,04 \\
\hline $\begin{array}{l}\text { I do not need to work overtime as I use to finish work within } \\
\text { working hours. }\end{array}$ & 3,30 \\
\hline I have enough time for my family and friends. & 3,72 \\
\hline I value the social benefits that the company offers me. & 4,41 \\
\hline \begin{tabular}{|l|} 
Work stress \\
\end{tabular} & 3,56 \\
\hline There is a lot of work to do in the office. & 5,11 \\
\hline I'm very busy with my work every day. & 4,86 \\
\hline I often fail to finish my work on time. & 2,67 \\
\hline My work requires a lot of time and effort. & 4,86 \\
\hline I'm always nervous because of work. & 2,39 \\
\hline I am difficult to fall asleep because of work. & 2,63 \\
\hline I feel a high-level tension at work. & 2,78 \\
\hline I feel a lot of pressure at work. & 3,21 \\
\hline \begin{tabular}{|l|} 
Job satisfaction \\
\end{tabular} & 4,29 \\
\hline \begin{tabular}{|l|} 
My income compared with colleagues in my office. \\
\end{tabular} & 4,09 \\
\hline My income compared to employees at other similar institutions. & 4,36 \\
\hline \begin{tabular}{|l|} 
Salary system in my office. \\
\end{tabular} & 3,90 \\
\hline Income equity in my office. & 4,07 \\
\hline Balance between my effort and salary. & 3,77 \\
\hline Performance evaluation mechanism in my office. & 3,55 \\
\hline Rationality of incentive mechanism in my office. & 3,77 \\
\hline $\begin{array}{l}\text { Respect from clients (Supervisors and/or Users who receive your } \\
\text { work). }\end{array}$ & 4,33 \\
\hline Respect from the public. & 4,94 \\
\hline $\begin{array}{l}\text { Clients' (Supervisors and/or Users who receive your work) } \\
\text { satisfaction with my services. }\end{array}$ & 4,81 \\
\hline $\begin{array}{l}\text { Clients' (Supervisors and/or Users who receive your work) trust } \\
\text { in my services. }\end{array}$ & 4,90 \\
\hline \begin{tabular}{|l|} 
Level of my job's enrichment. \\
\end{tabular} & 4,54 \\
\hline Appreciation from Supervisors. & 4,44 \\
\hline The way Supervisors treat employees. & 4,50 \\
\hline Managerial decision-making ability. & 4,39 \\
\hline Stability of my job. & 4,37 \\
\hline
\end{tabular}

\begin{tabular}{|c|c|}
\hline The opportunity to play my abilities at work. & 4,32 \\
\hline Mode of policy implementation in my office. & 3,96 \\
\hline Job promotion opportunities. & 3,12 \\
\hline Autonomy of my job in my office. & 4,64 \\
\hline Work environment & 4,42 \\
\hline A sense of achievement of my job & 4,72 \\
\hline Relationship with my colleagues & 4,89 \\
\hline Turnover intention & 2,75 \\
\hline I am thinking of leaving the organization I served now. & 2,95 \\
\hline $\begin{array}{l}\text { I am thinking of leaving the type of work I am currently working } \\
\text { on. }\end{array}$ & 3,11 \\
\hline I am looking for a new job recently & 2,39 \\
\hline I am looking for a new job next year & 2,56 \\
\hline
\end{tabular}

\subsubsection{Statistical analysis}

Main test data processing was carried out using structural equation modeling (SEM) statistical method that took a confirmatory approach, using Amos [19]. The validity test was done by looking at the factor loading value of each variable. Variable was considered valid if the factor loading value is \pm 0.50 or more [20]. The results of the validity test found 1 item of work-life balance was invalid, 4 items of work stress were invalid, 2 items of job satisfaction were invalid, and no invalid items on the turnover intention. All invalid items were removed from the model, and were recalculated. After all variables were declared valid, then the reliability test was performed by looking at the value of construct reliability (CR). CR values equal to or above 0.7 indicate good reliability; reliability is still acceptable if the CR value is between 0.6 and 0.7 , provided it is accompanied by a good indicator value of validity [20], based on table 3 . The reliability test results indicated that all research variables had good reliability, because they had a CR value> 0.7 . The model fit test was also conducted by looking at the values of GFI, AGFI, RMSEA, CMIN/DF, NFI, RFI, IFI, TLI, CFI, PNFI, PGFI based on table 4.

Table 3. Factor Loadings of Items and Construct Reliability of Each Variable.

\begin{tabular}{|c|c|}
\hline \multicolumn{2}{|l|}{ Work-life balance } \\
\hline The company facilitates work-life balance. & 0,812 \\
\hline My supervisor emphasize work-life balance. & 0,732 \\
\hline There is enough time for recreation activities. & 0,792 \\
\hline $\begin{array}{l}\text { I do not need to work overtime as I use to finish work within } \\
\text { working hours. }\end{array}$ & 0,748 \\
\hline I value the social benefits that the company offers me. & 0,685 \\
\hline Construct Reliability (CR) of work-life balance & 0,932 \\
\hline \multicolumn{2}{|l|}{\begin{tabular}{|c|} 
Work Stress \\
\end{tabular}} \\
\hline I'm always nervous because of work. & 0,522 \\
\hline I am difficult to fall asleep because of work. & 0,621 \\
\hline I feel a high-level tension at work. & 0,821 \\
\hline Ifeel a lot of pressure at work.. & 0,771 \\
\hline Construct Reliability (CR) of work stress. & 0,786 \\
\hline \multicolumn{2}{|l|}{\begin{tabular}{|l} 
Job Satisfaction \\
\end{tabular}} \\
\hline My income compared to employees at other similar in stitutions. & 0,548 \\
\hline Salary system in my office. & 0,527 \\
\hline Income equity in my office. & 0,581 \\
\hline Balance between my effort and salary. & 0,619 \\
\hline Performance evaluation mechanism in my office. & 0,654 \\
\hline Rationality of incentive mechanism in my office. & 0,602 \\
\hline $\begin{array}{l}\text { Respect from clients (Supervisors and/or Users who receive your } \\
\text { work). }\end{array}$ & 0,733 \\
\hline
\end{tabular}




\begin{tabular}{|l|l|}
\hline $\begin{array}{l}\text { Clients' (Supervisors and/or Users who receive your work) } \\
\text { satisfaction with my services. }\end{array}$ & 0,532 \\
\hline $\begin{array}{l}\text { Clients' (Supervisors and/or Users who receive your work) trust } \\
\text { in my services. }\end{array}$ & 0,581 \\
\hline Level of my job's encrichment. & 0,640 \\
\hline Apprecition from Supervisors. & 0,646 \\
\hline The way Supervisors treat employees. & 0,650 \\
\hline Managerial decision-makin ability. & 0,768 \\
\hline Stability of my job. & 0,747 \\
\hline The opportunity to play my abilities at work. & 0,754 \\
\hline Mode of policy implementation in my office. & 0,617 \\
\hline Job promotion opportunities. & 0,504 \\
\hline Autonomy of my job in my office. & 0,756 \\
\hline Work environment. & 0,559 \\
\hline A sense of achievement of my job. & 0,783 \\
\hline Contruct Reliability (CR) of job satisfaction. & 0,962 \\
\hline \multicolumn{1}{|c}{ Turnover Intention } & 0,878 \\
\hline I am thinking of leaving the organization I served now. & 0,731 \\
\hline $\begin{array}{l}\text { I am thinking of leaving the type of work I am currently working } \\
\text { on. }\end{array}$ & 0,713 \\
\hline I am looking for a new job recently. & 0,895 \\
\hline I am looking for a new job next year. & \\
\hline Construct Reliability (CR) of turnover intention. & 0 \\
\hline
\end{tabular}

Table 4 Goodness of Fit Measurement

\begin{tabular}{|l|l|l|l|l|}
\hline Category & Parameter & \multicolumn{1}{|c|}{$\begin{array}{c}\text { Recommended } \\
\text { value }\end{array}$} & \multicolumn{2}{|c|}{ Value } \\
\hline $\begin{array}{c}\text { Absolute } \\
\text { measures }\end{array}$ & GFI & $\geq 0,90$ & 0,786 & $\begin{array}{c}\text { Marginal } \\
\text { Fit }\end{array}$ \\
\cline { 2 - 5 } & AGFI & $\geq 0,90$ & 0,736 & $\begin{array}{c}\text { Marginal } \\
\text { Fit }\end{array}$ \\
\cline { 2 - 6 } & RMSEA & $\leq 0,08$ & 0,073 & Good Fit \\
\cline { 2 - 6 } & CMIN/DF & $\leq 3$ & 2,166 & Good Fit \\
\hline $\begin{array}{c}\text { Incremental } \\
\text { measures }\end{array}$ & NFI & $\geq 0,90$ & 0,815 & $\begin{array}{c}\text { Marginal } \\
\text { Fit }\end{array}$ \\
\cline { 2 - 6 } & RFI & $\geq 0,90$ & 0,784 & $\begin{array}{c}\text { Marginal } \\
\text { Fit }\end{array}$ \\
\cline { 2 - 6 } & IFI & 20,90 & 0,891 & $\begin{array}{c}\text { Marginal } \\
\text { Fit }\end{array}$ \\
\cline { 2 - 6 } & TLI & $\geq 0,90$ & 0,871 & $\begin{array}{c}\text { Marginal } \\
\text { Fit }\end{array}$ \\
\cline { 2 - 6 } & CFI & 0,90 & 0,889 & $\begin{array}{c}\text { Marginal } \\
\text { Fit }\end{array}$ \\
\hline $\begin{array}{c}\text { Parsimony Fit } \\
\text { measures }\end{array}$ & PNFI & $0-1$ & 0,700 & Good Fit \\
\cline { 2 - 5 } & PGFI & $0-1$ & & Good Fit \\
\hline
\end{tabular}

\subsubsection{Direct effect test}

Hypotheses testing of direct relationships were done by looking at the value of the Critical Ratio (C.R.) and the Estimated Probability $(\mathrm{P})$ value in the Regression Weights table, where the hypothesis was accepted if the value of C.R. $>1,648$ (one-tailed) and P $<0.05$. From the results of the structural model test, found that $\mathrm{H} 1$ was rejected based on table 5 .

Table 5. Test Result of Direct Effect Hypotheses

\begin{tabular}{|l|l|l|l|l|}
\hline & C.R. & \multicolumn{1}{|c|}{ P } & \multicolumn{1}{c|}{ Result } & Conclusion \\
\hline H1 & -0.683 & 0.945 & Not Significance & Rejected \\
\hline H2 & 3.396 & $* * *$ & $\begin{array}{l}\text { Positively } \\
\text { Significance }\end{array}$ & Accepted \\
\hline H3 & 4.784 & $* * *$ & $\begin{array}{l}\text { Positively } \\
\text { Significance }\end{array}$ & Accepted \\
\hline H4 & -2.499 & 0.012 & $\begin{array}{l}\text { Negatively } \\
\text { Significance }\end{array}$ & Accepted \\
\hline H5 & -3.542 & $* * *$ & $\begin{array}{l}\text { Negatively } \\
\text { Significance }\end{array}$ & Accepted \\
\hline
\end{tabular}

\subsubsection{Mediating effect test}

Hypotheses testing of mediation effect were done by looking at the Estimate value in the Standardized Indirect Effects table or by multiplying the two values of the direct relationship effect (dependent $\rightarrow$ mediator $\times$ mediator $\rightarrow$ independent). Mediation effect criteria were determined following the standards of reference [21], based on table 6 .

Table 6. Test Result of Mediating Effect Hypotheses

\begin{tabular}{|c|c|c|c|}
\hline & Direct Effect & Indirect Effect & Conclusion \\
\hline H6 & $\begin{array}{l}\text { WLB } \rightarrow \text { TI } \\
\text { (Not } \\
\text { Significance) }\end{array}$ & $\begin{array}{l}\mathrm{WLB} \rightarrow \text { js } x \mathrm{j} \rightarrow \mathrm{TI} \\
0.471 \times 0.315 \\
=-0.148365 \\
=-0.148\end{array}$ & $\begin{array}{l}\text { Indirect-only } \\
\text { mediation } \\
\text { (Accepted) }\end{array}$ \\
\hline $\mathrm{H} 7$ & $\begin{array}{l}\mathrm{WS} \rightarrow \mathrm{TI} \\
0.285\end{array}$ & $\begin{array}{l}\mathrm{WS} \rightarrow \mathrm{JSxJS} \rightarrow \mathrm{TI} \\
-0.214 \times-0.315 \\
=0.06741 \\
=0.068\end{array}$ & $\begin{array}{l}\text { Complementary } \\
\text { mediation } \\
\text { (Accepted) }\end{array}$ \\
\hline
\end{tabular}

From table 6 above, it can be seen that job satisfaction successfully played a mediating role in this study. The effect of job satisfaction mediation on work life balance and turnover intention relationships was indirect only mediation, meaning that there was a relationship effect when mediated, but there was no direct relationship effect. While the mediating effect of job satisfaction on work stress relationships and turnover intention was complementary mediation, meaning that the effects of mediated relationships and direct relationships were both exist and pointed at the same direction based on fig. 2 . 


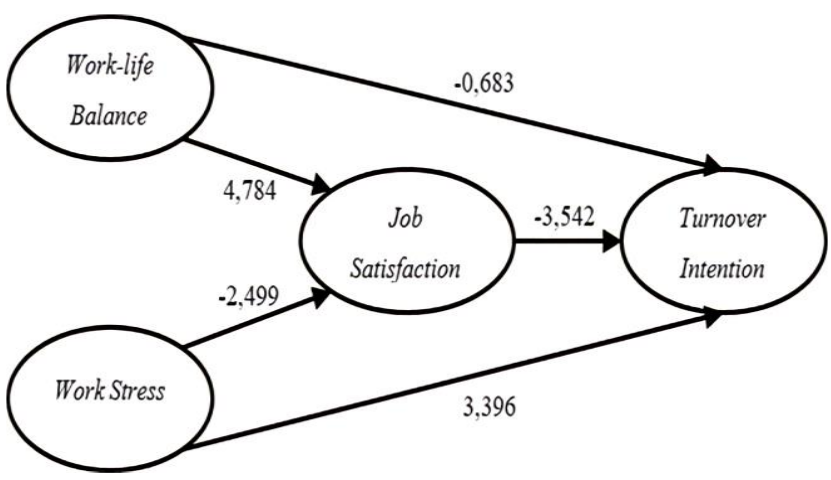

Figure 2 Hypotheses model results

\subsection{Discussion}

\subsubsection{Work Life Balance}

Hypotheses test results indicated that the relationship between work life balance and turnover intention was negative, but statistically proven to be insignificant or in other words there was no effect of work-life balance on turnover intention in the Deputy for Enforcement of AntiCorruption Institution. This condition is similar to research conducted by reference [22] on scientists and engineers working in the Research \& Development (R\&D) industry, who found that the relationship between family interference with work (FIW) and turnover intention was small and not statistically significant, whereas work interference with family (WIF) had no significant relationship on turnover intention. If we look at the characteristics of this institution, the demand for the amount of time spent on work should not be an objection for employees. Employees realized that it was their nature to work with flexible working hours. Therefore, they must be ready when needed. Although employees often worked overtime to complete their work, the average respondent's answers indicated that the desire to leave the organization was rather low. According to reference [22], the lack of relationship between these two variables could be caused by what they called as the "survivor effect", meaning that employees prefer to stay where they work now rather than have to go out with conditions that are not necessarily as good as where they work this time. Thus, it was natural that there was no relationship between work life balance and turnover intention in this Institution. The result of the hypotheses also proved that statistically work life balance had a significant positive effect on job satisfaction. These results were similar to the results in previous studies which showed that there was a significant positive influence in the relationship between work-life balance and job satisfaction $[3,6,9$, 15]. Besides, reference [6]found that the element of organizational where employees work also influenced this relationship. Also, reference [23] revealed that employees Employees who were well-known and proud to work for their employer will be pleased with their work. In addition to corporate pride, superiors' and organizations' encouragement for work-life balance were essential in ensuring employee job satisfaction [6, 24]. Overall, the average respondent's answers agreed enough that the implementation of work life balance had been implemented well at this institution. Then, the assistance involves implementing flexible working hours and maintaining a family, gathering, organizing blood donor social activities, and holding employee's week which contains sports competitions and art competitions between work units which the support covers in the form of providing facilities such as sports rooms and dormitory for employees who cannot go home to complete their work.

\subsubsection{Work stress}

Hypotheses test results indicated that there was a positive influence on the relationship between work stress and turnover intention. Overall, it was known that the average level of work stress was rather high, but the turnover intention of the employee was quite low. It is caused that the work stress indicator in contributing the high average value was an indicator of work stress related to work load, which when tested for validation was declared not significant to represent the work stress while valid indicators, all of which were representations of negative emotion, were recognized by respondents as quite low. Thus, a positive relationship was created in this relationship, which states that a low level of employee work stress was associated with a low level of employee turnover intention. This positive relationship between work stress and turnover intention was also found in the results of previous studies conducted by [9, 13, 14]. High-level tension and a lot of pressure at work were strong indicators that represent work stress. Griffin (2010) in reference [25] stated that work stress could occur when a person felt violence, tension, anxiety, frustration, worry, and work-related difficulties. Thus, it was not about how much work load (work load) employees received, but how they felt (negative emotion) when receiving the workload that causes work stress. In this institution, this tension might arise because employees were faced with cases of large corruption, which involve top-level officials who had a very strategic position (big fish). While the pressure might arise because employees were faced with high expectations from the public to be able to resolve the large case so that state financial losses caused by corruption could be immediately restored, but support for the completion of the case was still not felt by employees, whether it came from Government, for example there were policies that limit the institution in carrying out the task of enforcing criminal acts of corruption, or it could be from within the institution itself. Hypotheses test result also showed that there was a statistically significant negative relationship between work stress and job satisfaction. These results were similar to previous studies where work stress had a 
direct negative effect on job satisfaction $[9,16,17]$. From the overall responses of respondents, it was known that the average employee work stress related to negative emotion was rather low, while the average job satisfaction was rather satisfying. In the Deputy for Enforcement of this institution, the handling and settlement of cases was carried out in team collaboration, and there was a feeling of satisfaction when finishing handling a case, because the results could be enjoyed by the public.

\subsubsection{Job satisfaction as a mediator}

Job satisfaction successfully mediated work-life balance and turnover intention relationships, and without mediation, this relationship did not occur. Reference [21] refer to this condition as indirect-only mediation. These results were similar to previous studies by reference [ 9 , 10]. Job stability was believed to be a strong indicator of this relationship. This could be due to the organization as a state institution whose budget was sourced from the State Budget, so that in terms of work and finance it would be more secure when compared to organizations engaged in the private sector. Previous research revealed that job stability positively influenced organizational commitment which could reduce turnover intention, and that employees who felt safe in their work will had a low rate of absence and turnover [26-28]. In addition, organizational pride was also believed to had a strong influence on creating employee job satisfaction.

Job satisfaction was also proven to mediate the relationship of work stress and turnover intention, where the mediating nature that was mentioned is referred to, by[21], as complementary mediation, meaning that both direct relationships and mediated relationships have a significant effect. Previous findings also proved that job satisfaction could mediate the relationship between work stress and turnover intention [4, 9, 17]. Reference [4] explained in more detail that organizational management satisfaction, reward satisfaction, and occupation satisfaction succeeded in mediating the relationship between negative emotion and turnover intention. In addition to job stability, satisfaction with the work environment was a strong indicator that represented employee satisfaction in this institution. The results of the initial interview stated that 6 out of 7 employees recognized that the work environment in the Deputy for Enforcement of this institution was conducive and comfortable so that it made the employees feel comfortable working at this institution. It was illustrated by a family friendly environment, coworkers who respected each other and trusted each other, relationships between colleagues who were not rigid making it easier to discuss or asked for advice, and colleagues who supported each other.

\subsubsection{Additional discussion}

Research investigating the relationship between work-life balance, work stress, job satisfaction, and turnover intention had raised an interesting variable to be discussed. The variable was organizational pride. Reference [29] in [6] defined organizational pride as providing a positive and encouraging work environment, which requires high social identification with companies. In this study, indicators that describe organizational pride could be found in indicators of employee satisfaction with respect received from the public. If we looked at the answers of respondents as a whole on the job satisfaction, it was found that the highest average value of employee satisfaction was the statement of respect from the public. As had been proven by reference [6] that organizational pride positively affected job satisfaction. Previous research by reference [23] also revealed that employees who were known and felt proud to work in their company would also feel satisfied with their work. Organizational pride was seen as able to play a central role in the company because organizational pride could increase stress resistance, increase employee commitment, and reduce turnover intention [6, 29,30]

\subsubsection{Implications}

While work-life balance was not shown to have a major impact on turnover intention in this report, it is crucial for these organizations to continue to provide practical support for employees in achieving work-life balance, whether through direct support from the agency, supervisors' supported to subordinate employees (supervisor work-life balance support), or through a combination of these methods, as well as through facilities, social benefits, and other programs that support the work life balance of employees. The institution also needs to examine further what can cause the emergence of negative emotions in work that can affect work stress, whether it comes from the employee himself (such as lack of soft skills or hard skills to complete his work) or from outside the employee (such as the absence superiors and co-workers support related to the task being carried out). By knowing the cause of the emergence of negative emotions, the organization can provide the right solution for employees. Organization also needs to consider employee satisfaction with regard to job stability, work environment, and how to implement policies in the office, as well as how to create pride in every employee who works at the organization in order to increase employee job satisfaction.

Because the Corruption Perception Index (CPI) in Indonesia is still below the 180 countries average GPA recorded by Transperancy International, which is 38 (the average CPI is 43), then support for corruption eradication in Indonesia must continue to be improved. The government needs to consider policies that help prevent acts of corruption, especially policies that can be applied by agencies that provide public services. In addition, the actions of certain parties who try to weaken the Anti-Corruption Institution in carrying out acts of corruption eradication also need to be a serious concern for the Government. The Anti-Corruption Institution 
should be seen as a partner of the Government to accelerate the realization of an Indonesia that is clean of corruption. State officials need to increase their awareness of the treatment or matters that lead to corruption and must dare to reject corrupt matters, and dare to carry out their duties and role with high integrity because they realize their role as role models for the community.

The community needs to support every policy made to prevent acts of corruption. The community also needs to increase their understanding of corruption and the effects that can be caused by acts of corruption, and thus be able to apply anti- corruption actions in daily life. In addition, because public respect is seen as important for XYZ Institution employees, the community may continue to provide full support for the XYZ Institution in carrying out their duties to eradicate corruption in Indonesia.

\subsubsection{Limitation and suggestions for future research}

It is needed further studies to investigate the relation between job satisfaction and turnover intention that should consider organizational pride as a variable suspected to affect job satisfaction and turnover intention. Besides, it should investigate the relationship between work-life balance and work stress, as well as any relationships that could emerge as a result of those relationships. Thus, further studies can further enrich the literature relating to work-life balance, work stress, job satisfaction, and turnover intention, which can be beneficial for organizations and other parties who need understanding and references regarding these variables.

\section{CONCLUSIONS}

Based on the results of the analysis and discussion of the hypotheses test, it can be concluded that the Work life balance did not have a significant negative effect on employee turnover intention in the Deputy for Enforcement of Anti-corruption institution in Indonesia. This condition is understood as the dedication of employees in combating corruption, where service is the main key in carrying out their duties. However, work life balance was proven to have a significant positive effect on job satisfaction of the Deputy for Enforcement of Anti-corruption institution in Indonesia. It means that the level of work-life balance of employees will have a comparable effect on the level of employee job satisfaction whereas work stress was proven to have a significant positive effect on employee turnover intention and a negative significant effect on the job satisfaction of the Deputy for Enforcement of Anti-corruption institution in Indonesia employees. Job satisfaction proved to have a significant negative effect on employee turn- over intention in the Deputy for Enforcement of Anti-corruption institution in Indonesia. The results also found that job satisfaction was proven to mediate worklife balance and employee turnover intention in the
Deputy for Enforcement of Anti-corruption institution in Indonesia, where the mediating effect that occurred in this relationship was indirect-only mediation. In addition, job satisfaction has also been proven to mediate work stress and employee turnover intention in the Deputy for the Corruption Eradication Commissionin Indonesia, where the mediating effect that occurs in this relationship is complementary mediation.

\section{REFERENCES}

[1] S. C. Clark, "Work/family border theory: a new theory of work/family balance," Hum. Relations, 2000, doi: 10.1177/0018726700536001.

[2] M. Zhang, R. W. Griffeth, and D. D. Fried, "Workfamily conflict and individual consequences," J. Manag. Psychol., 2012, doi: 10.1108/02683941211259520.

[3] W. R. Pasewark and R. E. Viator, "Sources of workfamily conflict in the accounting profession," Behav. Res. Account., 2006, doi: 10.2308/bria.2006.18.1.147.

[4] J. Liu, B. Zhu, J. Wu, and Y. Mao, "Job satisfaction, work stress, and turnover intentions among rural health workers: a cross-sectional study in 11 western provinces of China," BMC Fam. Pract., 2019, doi: 10.1186/s12875-019-0904-0.

[5] Widodo, "Metodologi penelitian, populer \& praktis," in Metodologi Penelitian, Populer \& Praktis, 2017.

[6] M. Mas-Machuca, J. Berbegal-Mirabent, and I. Alegre, "Work-life balance and its relationship with organizational pride and job satisfaction," J. Manag. Psychol., 2016, doi: 10.1108/JMP-09-2014-0272.

[7] D. S. Carlson, K. M. Kacmar, J. G. Grzywacz, B. Tepper, and D. Whitten, "Work-familybalance and supervisor appraised citizenhip behavior: the link of positive affect," J. Behav. Appl. Manag., vol. 14, no. 2, pp. 87-106, 2013.

[8] J. Hayman, "Psychometric assessment of an instrument designed to measure work life balance," Res. Pract. Hum. Resour. Manag., 2005.

[9] Y. Lu et al., "The relationship between job satisfaction, work stress, work-family conflict, and turnover intention among physicians in guang dong, china: a cross-sectional study," BMJ Open, vol. 7, no. 5, 2017, [Online]. Available: e014894.

[10] J. W. N. T. N. Kumara and S. F. Fasana, "Work life conflict and its impact on turnover intention of employees: the mediation role of job satisfaction," Int. J. Sci. Res. Publ., 2018, doi: 10.29322/ijsrp.8.4.2018.p7666. 
[11] R. G. Netemeyer, J. S. Boles, and R. McMurrian, "Development and validation of work-family conflict and family-work conflict scales," J. Appl. Psychol., 1996, doi: 10.1037/0021-9010.81.4.400.

[12] L. Surienty, T. Ramayah, M.-C. Lo, and A. N. Tarmizi, "Quality of work-life and turnover intention: a partial least square (pls) approach," Soc. Indic. Res., pp. 119:405-420., 2014.

[13] A. L. Hakim, Sudarmiatin, and Sutrisno, "The effect of work stress on turnover intention with work satisfaction and commitment as intervening variable (study at pt infomedia solusi humanika in malang),” Eur. J. Bus. Manag., 2018.

[14]A. M. Mosadeghrad, "Occupational stress and turnover intention: Implications for nursing management,” Int. J. Heal. Policy Manag., 2013, doi: 10.15171/ijhpm.2013.30.

[15] N. Rathi and M. Barath, "Work-family conflict and job and family satisfaction: Moderating effect of social support among police personnel," Equal. Divers. Incl., 2013, doi: 10.1108/EDI-10-20120092.

[16] L. Li et al., "Work stress, work motivation and their effects on job satisfaction in community health workers: A cross-sectional survey in China," BMJ Open, 2014, doi: 10.1136/bmjopen-2014-004897.

[17] A. Tziner, E. Rabenu, R. Radomski, and A. Belkin, "Work stress and turnover intentions among hospital physicians: The mediating role of burnout and work satisfaction," Rev. Psicol. del Trab. y las Organ., 2015, doi: 10.1016/j.rpto.2015.05.001.

[18] P.E. Spector, (1997), "Job satisfaction: application, assessment, causes and consequences, sage publications, london.," Hum. Relations, 1997.

[19]B. M. Byrne, Structural equation modeling with amos: basic concepts, applications, and programming, 3rd edition. 2016.

[20] Hair, "Multivariate data analysis," Food Chemistry. 2014.

[21] X. Zhao, J. G. Lynch, and Q. Chen, "Reconsidering baron and kenny: myths and truths about mediation analysis," J. Consum. Res., 2010, doi: 10.1086/651257.

[22] C. Post, N. DiTomaso, G. F. Farris, and R. Cordero, "Work-family conflict and turnover intentions among scientists and engineers working in R\&d," J. Bus. Psychol., 2009, doi: 10.1007/s10869-0099089-1.

[23] R. Van Dick et al., "Should i stay or should i go? explaining turnover intentions with organizational identification and job satisfaction,” Br. J. Manag., 2004, doi: 10.1111/j.1467-8551.2004.00424.x.

[24] G. S. Armstrong, C. A. Atkin-Plunk, and J. Wells, "The relationship between work-family conflict, correctional officer job stress, and job satisfaction," Crim. Justice Behav., 2015, doi: 10.1177/0093854815582221.

[25] E. G. Lambert, H. Qureshi, J. Frank, C. Klahm, and B. Smith, "Job stress, job involvement, job satisfaction, and organizational commitment and their associations with job burnout among indian police officers: a research note," J. Police Crim. Psychol., 2018, doi: 10.1007/s11896-017-9236-y.

[26] R. Luna Arocas and J. Camps Torres, "Prácticas de alto rendimiento: un enfoque configuracional aplicado al caso español," Prácticas alto Rend. un enfoque Config. Apl. al caso español, 2008, doi: 10.5209/CESE.10219.

[27] B. Cross and A. Travaglione, "The times they are achanging: who will stay and who will go in a downsizing organization?," Pers. Rev., 2004, doi: $10.1108 / 00483480410528823$.

[28] M. Alzayed and M. Ali Murshid, "Factors influencing employees' intention to leave current employment in the ministry of information in kuwait," Aust. J. Bus. Sci. Des. Lit. www.raoaustralia.org ISSN, 2017.

[29] T. Kraemer and M. H. J. Gouthier, "How organizational pride and emotional exhaustion explain turnover intentions in call centers: A multigroup analysis with gender and organizational tenure,” J. Serv. Manag., 2014, doi: 10.1108/JOSM07-2013-0173.

[30]K. A. Appleberg, "The construction of a nomological network for organizational pride," 2005.

[31] S. Ajgaonkar, "Techniques Used to manage stress and its impact on middle management's performance in the hospitality industry in india (Doctoral Dissertation, Auckland University of Technology), 2006.

[32] G.S. Armstrong, C.A. Atkin-Plunk, J. Wells, "The relationship between work-family conflict, correctional officer job stress, and job satisfaction," Criminal Justice Behaviour, Vol. XX, No. X, 1-17, 2015.

[33] N.Arshadi, H. Damiri, "The relationship of job stress with turnover intention and job performance: moderating role of obse," Procedia - Social and Behavioral Sciences, 84, 706-710, 2013. 
[34] M.Askiyanto, B.E Soetjipto, Suharto, "The effect of workload, work stress and organizational climate on turnover intention with work satisfaction as an intervening variable (study at pt bri life and health insurance of malang). European J. of Business and Management, Vol.10, No.12, 2018.

[35] B. Bano and R.K. Jha, "Organizational role stress among public and private sector employees: a comparative study," The Lahore J. of Business, 2336, 2012.

[36] B.M. Byrne, Structural equation modeling with amos: basic concepts, applications, and programming, 3rd edition, New York: Routledge, 2016.

[37] N. Ding, B. Liu, "Chinese public sector employee's age, emotional dissonance, work meaningfulness, and perceived stress," Social Behavior and Personality, Vol. 47, Issue 1, e7280, 2019.

[38] M.R. Frone, M. Rusell, M.L. Cooper, "Prevalence of work-family conflict: are work and family boundaries asymmmetrically permeable?. J. of Organizational Behavior, Vol. 13, 723-729, 1992.

[39] J.H. Greenhaus, N.J. Beutell, "Sources of conflict between work and family roles," Academy of Management Review, Vol. 10, No. 1, 76-88, 1985.

[40] J.H. Greenhaus, G.N. Powell, "When work and family are allies: a theory of work-family enrichment," Academy of Management Review, Vol. 31, No. 1, 72-92, 2006.

[41] S. Huang, Z. Chen, H. Liu, and L. Zhou, "Job satisfaction and turnover intention in china," Chinese Management Studies, Vol. 11, No. 4, 689706, 2017.

[42] March 12, 2019, [Online]. Available : https://www.lembagaxyz.go.id/id/publikasi/penang anan-perkara

[43] January, 2019/ [Online]. Available : https://www.lembagaxyz.go.id/id/tentang-lembagaxyz/struktur-organisasi

[44] January, 2019, [Online]. Available : https://www.menpan.go.id/site/kelembagaan/lemb aga-non- struktural-2

[45] June 26, 2019, [Online]. Available : https://www.transparency.org/cpi2018,

[46] M. Jamal, "Burnout among canadian and chinese employees: a cross-cultural study", European Management Review, Vol. 2, 224-230, 2005.

[47]M. Jamal, "Job stress and job performance controversy: an empirical assessment,"
Organizational Behavior and Human Performance, Vol. 33, 1-21, 1984

[48] G. Kaya Özbağ, G.C. Ceyhun, "Does job satisfaction mediate the relationship between workfamily conflict and turnover? A Study of Turkish Marine Pilots. Procedia, Social and Behavioral Sciences, 140, 643-649, 2014

[49] KPK. (2019). Lampiran Laporan Tahunan KPK 2018 Kedeputian Penindakan, [Online]. Available : https://www.kpk.go.id.

[50] KPK. (2014). Laporan Tahunan Lembaga XYZ Tahun 2013, [Online]. Available : https://www. kpk.go.id.

[51] KPK. (2015). Laporan Tahunan KPK Tahun 2014. [Online]. Available : https://www. kpk.go.id.

[52] KPK. (2016). Laporan Tahunan KPK Tahun 2015. [Online]. Available : https://www. kpk.go.id.

[53] KPK. (2017). Laporan Tahunan KPK Tahun 2016. [Online]. Available : https://www. kpk.go.id

[54] KPK. (2018). Laporan Tahunan KPK Tahun 2017. [Online]. Available : https://www. kpk.go.id.

[55] KPK. (2019). Laporan Tahunan KPK Tahun 2018. [Online]. Available : https://www. kpk.go.id.

[56] D.M. Levine, D.F. Stephan, T.C. Krehbiel, M.L. Berenson, Statistics for managers: using microsoft ${ }^{\circledR}$ excel, 5 th edition. New Jersey: Prentice Hall, 2008.

[57]L. Lu, A.C.C. Lu, D. Gursoy, N.R. Neale, "Work engagement, job satisfaction, and turnover intentions," International J. of Contemporary Hospitality Management, Vol. 28, No. 4, 737-761, 2016.

[58] N.K. Malhotra, Marketing research: an applied orientation, 6th edition. New Jersey: Prentice Hall, 2010.

[59] H.Naburi, P. Mujinja, C. Kilewo, N. Orsini, T.Bärnighausen, K. Manji, and A. M. Ekström, "Job satisfaction and turnover intentions among health care staff providing services for prevention of mother-to-child transmission of hiv in dar es salaam," Tanzania. Human resources for health 15(1), 61, 2017.

[60] Quah and S.T. Jon, "Anti-corruption agencies in asia pacific countries: an evaluation of their performance and challenges," Singapore,https://www.transparency.org/files/cont ent/feature/2017_A CA_Background_Paper.pdf, 2017. 
[61] T. Saleem, S. Gul, "Drivers of turnover intention in public sector organizations: pay satisfaction, organizational commitment and employment opportunities," Middle-East J. of Scientific Research, 17(6), 697-704, 2013.

[62] U. Sekaran and R. Bougi, Research methods for business: a skill building approach, United Kingdom: John Wiley and Sons Ltd, 2010.

[63] S. Sumarsono, "Metode riset sumber daya manusia, Yogyakarta: Graha Ilmu, 2004.

[64] K. Tanwar and A. Prasad, "The effect of employer brand dimensions on job satisfaction: gender as moderator," Managemenet Decision, Vol. 54, No. 4, 854-886, 2016. 